\title{
NCAA Academic Reform: History, Context and Challenges
}

\author{
Michael Oriard \\ Oregon State University
}

\begin{abstract}
The purpose of this article is to offer a sociohistorical overview of academic reform in the National Collegiate Athletic Association (NCAA). To do so, the author draws heavily from football history and its association with academic reform in the broader intercollegiate athletics context. Intercollegiate athletics has undergone significant changes in professionalism and academic integrity over time-something that suggests the current dysfunctional structure can be systemically changed, too.
\end{abstract}

I have been charged with laying out the broad context for the general topic of the colloquium, and for the keynote addresses and responses that follow. As a cultural historian, my focus has been on football, and I will focus my remarks on what I know best. I am fully aware of the irritation among advocates for nonrevenue and women's sports when speakers focus only on football and men's basketball. But football drove the development of college sports in this country, and along with men's basketball, it has driven the academic reform agenda since the 1980s. Moreover, the two so-called revenue sports—at the most elite level—created the full-time, year-round model for all sports in not just Division I but also Division II. From my view, despite the higher graduation rates, particularly in women's sports, this model has not worked to the benefit of these athletes, whose losses are merely the collateral damage from policies dictated by football and men's basketball. All of this suggests thinking about academic reform means thinking primarily about football and men's basketball, but that does not exclude thinking about how a single set of standards or requirements serves or does not serve the interests and needs of all athletes in all sports.

\section{Part One}

I'll begin, then, by setting up the historical context. ${ }^{1}$ The era of academic reform did not truly begin until the 1980s, but the criticism of priorities and practices in intercollegiate sports, and thus an implicit call for reform, is nearly as old as college sports themselves. As Ron Smith has pointed out, controversy began with the second intercollegiate competition, a boat race between Harvard and Yale three years after their initial race in 1852, over Harvard's use of a coxswain from the

Oriard is Associate Dean in the College of Liberal Arts, Oregon State University, Corvallis, OR. 
1852 boat who had subsequently graduated. Yale protested but Harvard refused to remove him from the boat and proceeded to win (Smith, 2011).

Questions of eligibility were bitterly argued over for the next half-century, because college sports had no traditions, no governing body, and minimal institutional control. Our more recent wrangling over "initial eligibility" has been entirely an academic issue, but this was not so in this earlier period, when disputes more fundamentally concerned whether the athlete was an actual student at the college for which he was competing. That coxswain in 1855 was a Harvard man, but a graduate rather than a current student. Clearly that could not be allowed, but whether current students in the graduate and professional schools-law, medicine, and theology-should be allowed to play continued to be an issue well into the twentieth century.

Graduate students, at least, were actual students. The eligibility of what might euphemistically be called "part-time" or "irregular" students became an issue due to the win-at-all-costs ethic that Americans even at the most elite institutions of higher education brought to athletic competition. What became more bluntly known as "tramp athletes," who enrolled for fall term only and never visited a classroom, or who moved from school to school for a better deal, were part of the college football world in the 1880s and 1890s, as were bitter feuds between schools over their eligibility.

The grounds for objecting to tramp athletes seem obvious. But eligibility was also tied to a British definition of "amateurism" that was class-based and incompatible with American democratic principles. Not just tramp athletes, but also regular students who earned expense money by playing summer baseball were deemed to violate the amateur code. The NCAA still adamantly insists on amateurism, but what constitutes "amateurism" today would have appalled its champions at the turn of the twentieth century. Playing summer baseball for expense money could get you banned from college football. In January 2012, Oklahoma State won the Rose Bowl behind a twenty-eight-year-old quarterback who played five years of minor league baseball before enrolling in college. In the early years of college sports, any payment of tuition or fees or living expenses was a mark of "professionalism." Today, tuition, room, and board constitute an athletic scholarship, which is fundamental to collegiate amateurism. Today, instead, we are wrestling with the living expenses part of the standard scholarship, in relation to a proposal to provide an extra $\$ 2,000$, which is roughly half of what financial aid policies typically judge the Full Cost of Attendance. While high- and low-revenue programs wrestle with the economic impact, the official NCAA position is that compensation up to the full cost of attendance would still be within the bounds of amateurism, while anything beyond would be professionalism. However one feels about stipends for athletes, everyone should recognize that "amateurism" has been a shifting and flexible principle for a very long time.

To return to the historical context for academic reform: over the 1880s, 1890s, and early 1900s, as college athletics became increasingly organized, and shifted from student-run to institutional control, a four-point consensus on eligibility emerged that touched on academic principles: (a) competition should be limited to four years, (b) for only full-time undergraduate students, (c) in good academic standing, and (d) pursuing a degree. ${ }^{2}$ The basic principles remain the same today, though it now takes pages and pages of regulations to define each term. In these 
early years, in the absence of any governing body, institutions were to monitor the eligibility of their own athletes. Notice that whether freshmen should be eligible for the varsity team was not part of the consensus. Where freshmen were allowed to compete, it was typically at small schools concerned about having enough skilled players for the team. Where freshmen were ineligible, it was more often out of concern about tramp athletes than the academic well-being of freshmen. The desire was simply to limit participation to bona fide students of the institution, as defined by that institution.

As football passed baseball and crew to become the chief college sport, no season passed without its controversies over eligibility or professionalism, but only the brutality of the game could arouse broad public outrage. Here is the earliest case of the power of the media in driving or hindering reform in college sports. The modern newspaper, as created by Joseph Pulitzer in New York in the 1880s, along with William Randolph Hearst when he entered the New York market to challenge Pulitzer in 1895, exploited the violence of football in the same way it exploited sensational crimes to drive up circulations, and in so doing it created, or at least magnified, the sense of crisis in college football. In what has become the NCAA's familiar creation story, college football reached a crisis in the 1905 season, requiring the intervention of President Roosevelt himself, out of which came the first nation-wide organization to oversee the conduct of the game, which eventually took the name National Collegiate Athletic Association. Roosevelt was more concerned about the demoralizing consequences of professionalism in college athletics, but he recognized it was brutality putting the game at risk with the public, and his taming of the "football slugger" added to his stature as the president with the Big Stick. Parenthetically, the issue of brutality has again become a matter of urgent concern in just the past few years, as evidence of the long-term consequences of head trauma accumulates.

Out of the 1905 crisis came a revision of the rules to make football safer, most significantly legalization of the forward pass. The first convention, in 1906, also adopted a policy on academic eligibility: "No student shall represent a College or University in any intercollegiate contest, who is not taking a full schedule of work as prescribed in the catalogue of the institution" ("Proceedings," 1906; Falla, 1981 , p. 25). To my knowledge, this is the first official statement of an academic standard for college sports.

\section{Part Two}

Out of the 1905 crisis, of course, also came the NCAA itself, to recommend policy but without regulatory powers to enforce it until the 1940s. Beginning in 1895, with the forerunner of the Big Ten, conferences assumed whatever regulatory powers were attempted before the 1950s. In the 1920s, college football fully emerged as the country's greatest sporting spectacle (as opposed to baseball, the national pastime), with massive concrete and steel stadiums sprouting up throughout the country. A 10-point code adopted by the NCAA convention in December 1922 reveals what issues concerned member institutions at this time. Half of the principles addressed matters related to eligibility: freshmen not eligible for varsity competition; graduate students not eligible; eligibility limited to three years (not four); restrictions 
on transfers from other colleges (to be adopted through conferences); and athletes banned from playing on any team other than those representing their own institutions. These are the basic principles adopted in 1906, slightly revised. Three additional principles addressed issues of control and oversight: schools encouraged to organize into sectional conferences, which would establish rules and enforce them; faculty should have absolute control of athletics on campus; and district representatives of the NCAA should visit colleges in the region to advocate for the principles of the Association. And two final principles addressed ethical issues: the principles of amateurism, as defined by the Association, should be adhered to; and gambling should be suppressed (Falla, 1981, pp. 128-29, 137). Underlying all of these was a basic principle of home rule: the members of the NCAA were to agree on recommendations, but institutions were to govern their own athletic programs as they saw fit, unless they ceded authority to a conference.

The absence of explicitly academic matters is striking, presumably meaning that none seemed urgent at the time. Amateurism, whether expressed explicitly in the aforementioned ethical provisions or implicitly in the rules on eligibility, remained the key issue, or rather the "professionalism" that violated the amateur code. "Professionalism's" twin curse was "commercialism," which exploded in the 1920s along with all of those stadiums arising. These two primary concerns culminated in the well-known 1929 report by the Carnegie Foundation, the first real landmark in efforts to reform college athletics. The primary focus of the report, and all of the media attention it received at the time, dealt with the recruiting and subsidizing of college football players for the sake of a commercial enterprise now staged in enormous stadiums that dwarfed any academic building on campus. But Chapter VI, titled "Athletic Participation and Its Results," included information about the academic standing of athletes relative to nonathletes that provides an interesting touchstone for the issues facing us today. In a section on "Scholastic Requirements and Their Administration" the report was mildly positive, noting that academic standards had risen over the past twenty years, though how rigorously they were applied was more difficult to assess. The principle author, Howard Savage, cited several incidents of what he termed "conflicts between athletic ambitions and academic standards": a president, trustee, or alumnus pressuring the registrar or overriding the faculty to admit an academically unqualified athlete; an athlete staying eligible "through the passing of an examination under circumstances that were, to say the least, unusual"; and a general questioning of academic standards at "certain Catholic institutions" (read Notre Dame here).

Except for the quaintness of the language, the Knight Commission or the Drake Group could have issued the concluding statement last week:

Faculties, trustees, and even college or university presidents are not as yet united as respects the maintenance of strict requirements in the face of the supposed benefits that can be wrung from winning teams. The fact that all of these supposed advantages are tinged at one point or another with the color of money casts over every relaxation of standards a mercenary shadow (Savage et al., 1929, p. 119).

But Savage et al. also reported the results from examining the academic records of 2,787 athletes and 11,480 nonathletes at 52 colleges and universities. In general, 
the differences between athletes and nonathletes were negligible and not statistically meaningful (Savage et al., 1929):

- Athletes actually had higher average course loads and graduation rates, but slightly lower grades and "very slightly" higher rates of academic probation;

- Athletes took a semester longer to graduate;

- Athletes took more "easy" courses than nonathletes, but also more "hard" ones;

- Regarding athletes' marginally lower grades, football players were at the bottom (interesting, along with polo players!), but $95 \%$ of athletes overall progressed to the following semester (compared with $90 \%$ of nonathletes);

- And on intelligence tests, nonathletes scored only slightly higher; on one of the major ones, the Pennsylvania Achievement Test, athletes scored marginally higher than nonathletes (636.37-615.55), though football players (at 609.42) fell slightly below the nonathletes.

Big-time college athletics were controversial in 1929, but not for academic failures. And public response to the report's charges about the recruiting and subsidizing of athletes is instructive for thinking about the climate in which reform efforts continue to take place today. The Carnegie Foundation's indictment of the schools that subsidized athletes received front-page attention wherever big-time football was played, but it appeared on a Thursday (October 24), followed by the local university's denial or a shrug of indifference, after which the newspapers refocused their attention on what really mattered-how the home team would fare in Saturday's game. The timing may have been bad-the report was published the very week that Wall Street crashed-but the dismissal by the press and the indifference of the football public would have guaranteed a lack of impact in any case.

By the time of the Carnegie Foundation report, big-time college football had simply become too important (too big to fail, one might say)_-to local communities and to the institutions depending on them-to be governed only by ethical and academic concerns. This was the era of intersectional football, when college football became a national sport with regional variants, whose champions competed against each other for local and regional pride. This was also the era when what John Thelin (1994) (following Daniel Boorstin) calls the Booster College, or what Douglas Toma (2003) terms Football U., came into being: universities built themselves on the renown of their football teams.

And this was the era when coverage of sports exploded in a new era of mass media. The daily newspaper with its separate sports section and massive Sunday issue emerged in the 1920s. Newspapers had contributed hugely to the sense of crisis over the brutality of football in the 1890s and early 1900s. Not in 1929. Newspapers now depended on sports news for circulations, and sportswriters had cozy relationships with the coaches of the teams they covered. Commercial radio began in 1921 and by the end of the 1920s was carrying football games throughout the day on Fall Saturdays on both local stations and national networks. College football feature films proliferated after 1925, and about $20 \%$ of the newsreel before the feature was devoted to sports, which meant college football in the Fall. By the end of the twenties, the media and college football were mutually dependent in ways now taken for granted, and sustained criticism of college sports, as opposed 
to the occasional rant, became all but unthinkable in the popular media. The general indifference of the football public to reform, fed by the most powerful media, is a crucial factor to consider when contemplating the prospects for reform, particularly academic reform, in college athletics today.

While football in the 1920s was already becoming the tail that wagged the college dog, it is important to recognize that the sport also played a genuinely progressive social role in this era. Here, the lesson from history is to prompt consideration whether it continues to play a comparable role today. College football, like higher education generally, was elitist from its beginnings in an era, when just $1-2 \%$ of Americans went to college. As late as 1940, the figure was still only $16 \%$. Football played a key role in democratizing American higher education, both actually and symbolically, as a predominantly WASP (White, Anglo Saxon Protestant) game celebrated in the late nineteenth century for embodying the spirit of Anglo Saxon racial superiority began to be dominated by the sons of working-class Irish, Italian, Polish, Slavic, and Jewish immigrants - at a time when anti-immigrant hysteria, fed by anti-Catholicism, was gripping the country. Notre Dame had a key role here, as football's first "America's Team," but representing the America of ethnic and religious outsiders. Working-class ethnic football players became an extremely conspicuous minority on football rosters over the 1920s and 1930s. In a study of the social profile of professional football players, for example-former collegians who had been top players at their schools - the historian Steven Riess calculated that 20\% of NFL players from 1935 to 1945 were either Slavic or Italian (Riess, 1991).

Given the class and ethnic transformation of college football, at a time when the intellectual abilities and academic performance of athletes, as documented by the Carnegie Foundation, seem to have been not markedly different from those of nonathletes, it is instructive that there developed in the popular culture a stereotype of the dumb jock that seems to suggest a general assumption that lots of football players were dummies, irrespective of the evidence. The alternative stereotype of the football star as campus god and handsome hero was more pervasive, but the dumb jock became a familiar figure in print and film in the 1930s. Andy Devine (remembered by my generation as Jingles, Wild Bill Hickok's comic sidekick in a 1950s TV western series) and Jack Oakie played this character in several films. The Oakie character in the 1941 film from the Thurber story "University Days," is named Boley Bolenciecwcz, not, say, Tommy Wilson, during an era when All-Americans, particularly in the East and Midwest, often had names like Bronko Nagurski, Frank Carideo, Alex Wojciechowicz, Sid Luckman, and Marshall Goldberg. Other fictional dumb jocks included Ivory Ivorson, Ox Lenihan, Adolph Kroger, and Pete Maciek. The figure of the dumb jock goes back to ancient Greece, but the American version in this period had a distinctly local ethnic flavor.

\section{Part Three}

Big-time college football entered a new era in the 1950s with the institution, at last, of the athletic scholarship in 1956. Throughout the 1930s "professionalism" remained the major source of controversy, as southern conferences became the first to approve athletic scholarships, while the Big Ten and Pacific Coast Conference continued to reject them but subsidized their athletes by providing jobs on campus or through alumni. The Big Ten and PCC condemned the southern schools for 
professionalism. The southern schools accused the northern and western schools of hypocrisy, for providing scam jobs (perhaps, cleaning snow off the sidewalks at the University of Southern California) rather than forthright scholarships. The NCAA, for the first time, took on enforcement powers at the December 1940 convention but did nothing with them until January 1948, when it approved "The Principles for the Conduct of Intercollegiate Athletics," otherwise known as the "Sanity Code."

Five of the "Principles" more or less reiterated the basics from the 1906 and 1922 conventions: (a) athletes held to the same academic standards governing other students; (b) one-year residency for transfers; (c) limit of three years of varsity competition; (d) restriction to undergraduates only; and freshmen ineligibility (Falla, 1981). But the key provision was the ban on financial aid for athletic ability, which directly clashed with the current practices at many universities, particularly in the South. Two years later, when the membership refused to expel the University of Virginia and six other institutions for violations, the Sanity Code was dead. In its place, at the January 1952 convention, the NCAA approved a 12-point code that significantly expanded on the 10-point code of 1922.

Half of the principles addressed various aspects of "professionalism" (Falla, 1981), in language as vague as my paraphrasing here:

4. Reconsider the free-substitution rule in football;

7. Limit the number and amount of financial grants to athletes, to come from the institution, not from alumni or boosters;

8. "[E]nlist the support of true lovers of wholesome college athletics, particularly in alumni areas, to reduce undesirable recruiting";

9. Strictly adhere to the letter and spirit of the rules, once they have been established by regional or national groups;

10. Ban all subsidies or gifts beyond what is regularly permitted by the institution or conference;

11. Eliminate excessive entertainment of prospective athletes.

But the other half either directly or indirectly addressed the academic welfare of college athletes, in contrast to that lack of concern in 1922:

1. Confine practice sessions to the recognized season of the sport (that is, no spring football), and limit or closely supervise out-of-season practices;

2. Limit the number of games in each sport, particularly football and basketball;

3. Reconsider postseason games in the light of pressures they create (i.e., a potential ban on bowl games);

5. Require normal academic progress toward a degree for purposes of eligibility;

6. Admit athletes only under the institution's published requirements;

12. Give close attention to the curriculum of the athlete, to assure that he is not diverted from his educational objective.

From our perspective today, the first three principles-attempts to limit the time commitment required for the sport-have been utterly ignored, as restrictions on seasons, postseasons, and off-seasons have been obliterated. Principles 5, 6, and 12, on the other hand, are all too familiar: they are the issues (initial eligibility, academic progress, and ultimate graduation) that we continue to wrestle with today. 
The 1950s was an era of unprecedented scandal in college sports: the pointshaving scandals in basketball and, in football, the cheating scandal at West Point in 1951, followed by the slush-fund scandals in the old Pacific Coast Conference that led to the dissolution of the conference by the end of the decade. The overriding problem with college football in the late 1940s and 1950s was termed "overemphasis," and this was the moment when the modern era of big-time college sports came into being, as universities had to choose whether to drop football (as several Catholic universities did), de-emphasize it (as the Ivy League most conspicuously did, banning bowl games and spring practice), or go along with the over-emphasized version. In finally solving the decades-long battle over "professionalism" by adopting athletic scholarships in 1956, the NCAA accepted "over-emphasis" as the norm. In addition, after decades of being organized simply by region, the NCAA in 1956 created "university" and "college" divisions, beginning the long process by which the major athletic powers would increasingly separate themselves from the rest. The 1950s thus marked a crucial turning point for American college sports.

Principles 5 and 6 of the 12-point code of 1952-normal academic progress and admission of athletes by regular university standards-became more specific in 1959, when the NCAA officially defined normal progress as a minimum of 12 credit hours per term; then in 1965, when it adopted the so-called 1.600 rule for financial aid, a measurement based on high school GPA ranking and test scores that projected a 1.6 college GPA, along with a requirement of a 1.6 GPA in college courses for continuing eligibility. The rule immediately became controversial because of concern about the validity of standardized tests and, soon, because of its potential conflict with university policies opening up admission to disadvantaged students. More pragmatically, it also restricted which athletes coaches could recruit. An attempt to abolish the rule at the 1971 convention failed, then another attempt, in 1973, succeeded, replacing the 1.600 rule with a simpler requirement of a 2.0 high school GPA for initial eligibility, and restoring institutional authority over determining normal progress (Falla, 1981).

The abolition of the 1.600 rule was part of a package of changes made at the 1972 and 1973 NCAA conventions that, I would argue (and I'm guessing that few would dispute), fundamentally redefined student athletes as athlete students. The 1972 convention made freshmen eligible for varsity competition in football and basketball, as they had been in other sports since 1968. Then at the 1973 convention, in addition to abolishing the 1.600 rule, members replaced the four-year scholarship with one-year renewable grants (following repeated unsuccessful attempts to do this since 1965), and at a special session later in the year, they divided the association into Divisions I, II, and III-a refinement of the "university" and "college" divisions created in 1956, that was further refined by the separation of Division I into I-A and I-AA in 1978.

These changes opened up college athletics to anyone with a high-school diploma, made her or him eligible as a freshman, and made renewal of scholarships dependent on satisfying the coach-and they did this at the moment when full racial integration was finally being achieved, creating a huge pool of talented athletes with inadequate educational backgrounds in too many cases. All of this should have been evident at the time. What could not have anticipated were several factors that would soon make college sports the full-time, year-round occupation that we now know. No one likely foresaw in 1973 that weight-training and watching game films 
would soon add hours to the athletes' time commitment, at the expense of sleep and study. Weight-lifting was just beginning to become a part of athletic training; it was mostly informal and never in-season (the assumption being that muscles needed rest, not further strengthening). Reels of film could not be easily copied, edited, or even projected; watching film was limited to after-dinner meetings with the offense in one room, the defense in another. All of this would change, in an environment transformed by media and revenues no one also could have foreseen in 1973, when athletic programs, like their universities, were struggling in a weak economy plagued by a combination of recession and inflation.

The changes of 1972-1973 put the NCAA on a collision course with academic scandal, and created Ground Zero for the world of continuous academic reform in which we still operate. No systematic data collection on academic performance and graduation rates was conducted until the federal government began mandating it in the 1980s, but case studies by sports sociologists and a few universities suggest the general state of affairs in this period. Recall that the 1929 Carnegie report found athletes and nonathletes graduating at about the same rate, whatever that rate was. Calculations by historian Steven Riess (or cited by Riess) based on varying sample sizes (and varying reliability), came up with graduation rates for professional football players from the 1930s through the 1960s ranging from 54.2 to 60 percent. In contrast, for a fairly large sample of NFL players in 1982 - that is, not quite a decade into the world created by the NCAA in 1972-73-just 31.5\% had college degrees (Riess, 1991).

Whatever the rates for earlier decades, a handful of case studies by sociologists in the 1970s and 1980s revealed declining rates, and some of them marked 1973 as a turning point. At Michigan State, $80 \%$ of freshmen athletes entering in 1953 graduated (compared with $45 \%$ of students overall); of those entering in 1973, $61 \%$ of athletes graduated compared with $62 \%$ overall. At Colorado State, $27 \%$ of football players in the 1970s graduated. At Minnesota, nine percent of basketball players from 1978 to 1983 graduated. At New Mexico, from 1970 to 1979, 21\% of football players and $28 \%$ of basketball players graduated. At Texas, between 1975 and 1981, $18 \%$ of basketball players graduated. At Memphis State, from 1973 to 1983, just six of 58 basketball players graduated, none of them Black. In the Big Eight conference, graduation rates for football players entering in Fall 1980 ranged from $41 \%$ for Missouri at the top to $16 \%$ for Oklahoma State at the bottom.

Among these studies, the most dramatic was conducted by Tulane University of its own student athletes from 1967 to 1984. In 1973, the mean SAT score for an incoming athlete in football or basketball was 1022, compared with 1114 for all undergraduates. By 1984, the average SAT for athletes in the revenue sports had dropped to 691, while scores for all students stayed roughly the same (up from 1114 to 1121). Not surprisingly, the Tulane study also found that the mean GPA for athletes in the revenue sports from 1980 to 1984 was 1.93 , compared with 2.73 for a sample of all undergraduates (for an overview, see Eitzen, 1987).

Abysmally lower graduation rates were scandalous but not "scandals," which are not the unsavory events themselves but the public awareness and reaction to them. The academic performance of college athletes first became "scandals" around 1980, when the New York Times, U. S. News \& World Report, Sports Illustrated, Newsweek, and other media leaders made them front-page or cover stories. "The Shame of College Sports," as Newsweek termed it, included altered transcripts, 
credit for courses not taken, students paid to take athletes' exams, athletes funneled into worthless classes to keep them eligible only to leave the university without an education. To appear in one of these stories was among a university president's worse nightmares, and it undermined the very reason for having a big-time athletic program in the first place-to enhance the university's reputation. The 1980s saw a steady stream of such scandals, featuring poster figures of college sports' failures such as Kevin Ross, Chris Washburn, and Dexter Manley, who tearfully testified before a Senate subcommittee in 1988 that, despite four years of college, he was essentially illiterate. There was also a series of ugly incidents when academic tutors of athletes such as Jan Kemp at Georgia, Linda Bensel-Meyers at Tennessee, Jan Gangelhoff at Minnesota, Norma McGill at Ohio State, and Caroline Owen at LSU blew the whistle on their schools' cheating, only to find themselves vilified or fired. Academic scandals of these sorts have, of course, occurred periodically ever since.

Institutions can choose to ignore low graduation rates, but not scandals. As these inevitable scandals unfolded, the NCAA scrambled to undo the damage it had done at the 1972 and 1973 conventions. I assume that the details of the academic reform movement since the 1980 s are more generally familiar than the earlier history I have covered, so I will move quickly over them. Proposition 48, approved at the 1983 NCAA convention and implemented in August 1986, required a score of 700 on the SAT, plus a 2.0 GPA in eleven core high school courses for initial eligibility. The use of standardized test scores provoked controversy and outrage, particularly from the presidents of historically Black colleges. With the long-overdue achievement of full integration by the 1970s, talented African American athletes with inadequate educational preparation were disproportionately affected by the relaxed admission standards, which meant that they were also disproportionately affected by attempts to strengthen standards. (Harry Edwards was a conspicuous defender of Prop 48, not in defense of standardized testing, but on the grounds that that raising academic expectations for Black high school athletes would be a good thing - the required 700 SAT, in fact, was too low-because they would rise to meet them.)

In 1989, the NCAA convention passed Proposition 42, denying financial aid to partial qualifiers (i.e., those with the requisite GPA or SAT but not both). Furiously attacked, it was rescinded the next year. The so-called "Reform Convention" of 1991, when university presidents conspicuously assumed leadership, included a limit on athletic participation of 20 hours per week in season, 8 hours out of season. That year, the Knight Commission on Intercollegiate Athletics issued its first report, proposing specific reforms and more broadly calling on presidents to assert more control. In 1992, Proposition 16 modified Proposition 48 by creating a sliding scale of SAT scores and GPA's, now in 13 core courses (by 2008 the number of core courses had risen to 16). In October 2011, the required 2.0 GPA in high school core courses was raised to 2.3, and the required GPA for transfers was raised from 2.0 to 2.5. The latest, and current, mechanism for academic reform, the Academic Progress Rate, or APR, was implemented in 2005, with the first penalties meted out in 2006.

Academic standards today, then, are governed by initial eligibility rules (a sliding scale by which, for example, a 700 SAT requires a 2.8 GPA while a 2.3 GPA needs a 900 SAT); by the APR (mandating academic progress that leads to roughly a 50\% Graduation Success Rate); and by a supposed limit on athletic participation 
of 20 hours a week in season and 8 hours a week out of season. Serious concerns about these standards include: (a) "SAT gaps" between athletes and nonathletes, typically over 200 points and exceeding 300 points at some schools; the reality of full-time athletic commitments (as much as 44 hours per week for football players according to the NCAA's own data), as opposed to the mandated limits; a minimum APR standard that is not very high, pegged to graduate only half of a team's athletes; the lower scores for football and men's basketball than for other sports; the lower scores for Black athletes than for White; the need for athletes to choose a major immediately rather than to explore, as other students can do; and the pressure to "cluster" athletes in less challenging majors-to have them "major" in eligibility.

To these issues I would add my own two broad concerns. First, the concurrent pursuit of victories and revenues creates enormous pressure to get the best athletes and keep them eligible, which continuously undermines efforts to make their education a true priority. And second, a serious uncertainty exists as to whether the education possible for college athletes today, under the current system and within today's broader sports culture and job market, benefits them in the long-term as college sports benefited those from my generation and earlier.

On that first point, I assume that the basic outline of the unrestrained pursuit of revenues since the 1970s is familiar: the creation of the College Football Association in 1976 through its victory before the Supreme Court in 1984 over television rights, which led to conference realignments and ever-growing television deals beginning in the 1990s, along with the bowl arrangements culminating in the Bowl Championship Series in 1998. Over the course of these developments, the preexisting gap between economic haves and have-nots widened and became more rigidly institutionalized. These revenues have been pursued within a larger sports culture utterly transformed by 24/7 sports media, the billions of dollars they generate, and the millions of dollars awaiting athletes good enough to make it in the NFL or NBA. There cannot be very many top high school athletes in this environment who arrive at college with education as their highest priority. And the stakes are so high for those who can make it to the next level that sport most likely remains the highest priority until professional options disappear.

My second broad concern addresses the implicit contract between college athletes and their universities by which the athletes are to receive a meaningful education in return for their athletic services. That is, I wonder about the long-term benefits of the education offered college athletes today, particularly for football and basketball players, most particularly for African American football and basketball players, whose situation is similar to that of the lower-class ethnic players of the 1920s and 1930s. In the absence of comprehensive or systematic data on this matter, there are bits of data that confirm what is generally assumed from considerable anecdotal evidence: college football from the 1920s through the 1960s and beyond did in fact help working-class, often ethnic outsiders enter the great American middle class. Consider the following. Riess (1991) found that $95.8 \%$ of former NFL players from the 1930s, and $99.1 \%$ from the 1950 s, ended up in white-collar jobs. Loy (1969) surveyed 845 athletes at UCLA, including 192 football players, who had won at least three varsity letters, and found that they entered postcollege careers with significantly higher occupational status than did their fathers. Finally, Sack (1987), in his analysis of Notre Dame football players from 1946 through 1965, found athletes did as well as nonathletes in their postcollege careers (and first-teamers did better), despite coming from lower socioeconomic backgrounds. 
The many examples of successful businessmen and CEO's who played college athletics reinforces the long-held idea that competitive sports are ideal training for success in later careers. In fact, this was one of the bases for women's demanding equal opportunities in school sports, to offset their disadvantages in later professional careers. To my mind, an enormously important question today-possibly the most important question-is whether college sports is still doing that for athletes, at public institutions as well as selective private ones, and for football and men's basketball players as well as swimmers and gymnasts. I am hoping that the NCAA will soon provide some answers to that question, from the findings from its GOALS and SCORE studies.

\section{Part Four}

This brings me in conclusion to the question, how can the historical framework that I have laid out help us think about the prospects for academic reform? First, history teaches us that the current structure of intercollegiate athletics is the result not of inexorable market forces but of institutional choices, however driven by those market forces. The NCAA was created in 1905-06. It was reinvented in the 1950s. It radically changed the experience of college athletes in the early 1970s. Its football elite radically changed the economic foundations in the 1980s and 1990s, and are changing it again today with astonishing new television contracts and the resulting conference realignments. The system of intercollegiate athletics that we have today, which seems impervious to systemic change, is in fact the product of past systemic changes and can be changed again.

This point is essential, because what has become since the 1980s a culture of scandal in college sports-scandal, followed by reform to prevent future scandal, in an endlessly repeatable cycle-presupposes the current structure and does nothing to address its systemic flaws. This point was made in a cover story of the Columbia Journalism Review this past fall, where the author describes the "Scandal Beat" of investigative reporters whose exposure of the latest corruption in college sports creates an illusion of meaningful reform while actually distracting attention from the need for systemic change (Libit, 2011). A similar argument can be made about the academic reforms that have essentially been driven since the 1980s, not by concern for education as the highest priority but by a desire to avoid scandal. Today, for example, raising academic standards through strengthening the APR and increasing its penalties begs all of the questions about whether the APR actually guarantees opportunities for a meaningful educational experience.

Obviously, it is important to ask what is possible for academic reform under the current structure, but little more can be expected beyond tweaking the APR, and even this tweaking is severely constrained:

- One set of rules governs all athletes in all sports, and those rules are driven by football and men's basketball;

- The APR governs both the economic haves and the have-nots, fueling the facilities arms race for high-revenue programs, while the rest struggle with inadequate resources;

- In the current two-pronged agenda of the NCAA-mandatory compliance with the APR and voluntary fiscal responsibility-it is impossible to reduce the pressures to get the best athletes and keep them eligible. 
But the APR is tied to the current structure, and while these things seem to unfold in slow motion, that structure has become vulnerable on many fronts:

- Conference realignments and the mad scramble for a spot in one of the BCS conferences are probably not completed, and they are already resulting in a severely widened gap between haves and have-nots. (The latest report on revenues and expenses from the NCAA has two-year-old data-which don't account, for example, for the new TV deals, but it captures the revenue disparities in the FBS that have been great for some time and will be dramatically exacerbated by the latest TV deals (Fulks, 2011).

- Growing contempt for the BCS, whether for its economic impact or, more simply, for its failure to reward the most deserving teams, is notably shared by several Congressional legislators as well as fans;

- Ongoing lawsuits over uncompensated use of athletes' images for commercial purposes (the O'Bannon case is scheduled to go to trial in 2013) appear to have very strong chance of succeeding;

- In just recent weeks (as I write), a cover story in the Atlantic Monthly ("The Shame of College Sports") written by the eminent historian Taylor Branch and the Chronicle of Higher Education ("What the Hell's Wrong with College Sports?") were unusually harsh and received wide attention.

The NCAA has been paying attention, but last summer's proposal to allow $\$ 2,000$ stipends was rejected in the fall and is back on the table. It will not go away. In fact, the resolution of this dispute could easily become the first rupture in the NCAA's present structure. Athletic programs that can afford the stipend cannot afford to let it drop, for fear that Congress or the courts will impose something more substantial. A split between institutions that offer or do not offer the stipend would widen the current separation between haves and have-nots into more distinct athletic universes. That could easily be just the beginning of truly systemic change, as institutions on either side of the divide would face different challenges and might feel forced to rethink their priorities. In this scenario, systemic change for financial reasons - the only kind that can drive such change-would open up opportunities for meaningful academic reform, too.

I do not want to get too deep into what-if speculation, but it is difficult to conceive the NCAA standing pat with a current structure plagued by such radical disparities in revenue. If Division I should separate into those that compensate athletes beyond the level of current scholarships and those that do not, the challenges for the two groups would be quite different. For the athletic elite, why would the shift stop here? A $\$ 2,000$ stipend is only halfway toward the full cost of attendance. But why stop even there? The full cost of attendance for those who generate the revenues is a pittance compared with the millions their coaches earn and the tens of millions that go to their institutions. What happens when the O'Bannon case over the licensing of athletes' images by their institutions goes to trial? The possibilities go on and on. Athletes with professional aspirations currently are not allowed to have agents or to transfer schools to improve their prospects. If the goal, or the legal mandate, is to do what is right for elite college athletes, how can this be done without abandoning the pretense of amateurism altogether? But what 
about the athletes in the sports that don't generate much revenue? And what about Title IX? I hope that a lot of athletics administrators are thinking hard about these matters right now.

For institutions outside the athletic elite, the challenges, and opportunities, would be utterly different. I cannot imagine a university president or board of trustees in the current system choosing radical de-emphasis. But if external forces impose de-emphasis, options currently unthinkable become possible. True, schools could continue competing as they do now, with scholarships but no stipends, in the shadow of the super conferences, but would the benefits to the institution warrant the expenditures required to do so? If not, envisioning an alternative might be like choosing a reset point for "system restore" on your computer. Which point do you choose, before things got mucked up?

There is no lack of proposals for academic reform out there today, from the Knight Commission, the Drake Group, and others, which would essentially reset the system at the NCAA's 1952 Principles: athletes treated as regular students and given a real opportunity to get a regular student's education. Such proposals, under the NCAA's current structure, usually seem quixotic. College sports have had no Golden Age, when students just showed up for tryouts and every athlete was on the dean's list. And I know that the Ivies and Division III have their own issues with athletics. But the 1950s marked a turning point, when some institutions opted for a complementary balance between academics and athletics, while others kept moving in a direction that culminated in the actions of the 1972 and 1973 NCAA conventions, and then in due course in the scandal-driven academic reform movement that followed.

There appears to be a growing consensus that the current system of college sports fails too many "student athletes" both as students and, in the case of those with professional potential, as athletes. The media have not played a decisive role in athletic reform, except to blunt it, since 1905, when the issue was brutality, not academics. A critical consensus emerging in the media today is primarily concerned with the economic exploitation of the young men who generate the revenues in football and basketball. No such media-driven mandate is present-or even possible, history would tell us_regarding academic reform. Universities, as always, will be on their own here.

It is important to think hard about what academic reform is possible within the current system. But we might also think about what could become possible when the old system collapses. That seems to be coming, and sooner rather than later.

\section{Notes}

1. Throughout this essay I draw on my published books Reading Football, King Football, and Bowled Over, but I do not clutter this text with references to them.

2. On the early history of American college sports, see particularly Smith (2011) and Watterson (2000).

3. Philip Taubman, "Faking of College Credits for Athletes Is Under Inquiry," New York Times, January 9, 1980; "Behind Scandals in Big-Time College Sports," U.S. News \& World Report, February 11, 1980; "The Shame of American Education," Sports Illustrated, May 19, 1980; "The Shame of College Sports," Newsweek, September 22, 1980. 


\section{References}

Branch, T. (2011). The shame of college sports. Atlantic. Retrieved online from http://www. theatlantic.com/magazine/archive/1969/12/the-shame-of-college-sports/8643/.

Eitzen, D.S. (1987). The educational experiences of intercollegiate student-athletes. Journal of Sport and Social Issues, 11(4), 15-30.

Falla, J. (1981). NCAA: The voice of college sports. Mission, KS: National Collegiate Athletic Association.

Fulks, D. (2011). Revenues \& expenses, 2004-2010. Indianapolis, IN: National Collegiate Athletic Association.

Libit, D. (2011). The scandal beat. Columbia Journalism Review. Retrieved from http:// www.cjr.org/cover_story/the_scandal_beat.php?page=all.

Loy, J. (1969). The study of sport and social mobility. In G. S. Kenyon (Ed.), Aspects of contemporary sport sociology: Proceedings of the C.I.C. Symposium on the Sociology of Sport, University of Wisconsin (pp. 101-119). Chicago: Athletic Institute.

Proceedings of the First Annual Convention of the Intercollegiate Athletic Association. (1906). New York, December 29, 1906 (accessed in Google books).

Riess, S.A. (1991). A social profile of the professional football player, 1920-82. In P.A. Staudohar \& J.A. Mangum (Eds.), The business of professional sports (pp. 222-246). Urbana, Champaign: University of Illinois Press.

Sack, A.L. (1987). College sport and the student-athlete. Journal of Sport and Social Issues, 11, 31-48. doi:10.1177/019372358701100103

Savage, H.J., et al. (1929). American college athletics. New York: Carnegie Foundation.

Smith, R.A. (2011). Pay for play: A history of big-time college athletic reform. Urbana, Chicago, and Springfield: University of Illinois Press.

Thelin, J.R. (1994). Games colleges play: Scandal and reform in intercollegiate athletics. Baltimore: Johns Hopkins University Press.

Toma, J.D. (2003). Football U.: Spectator sports in the life of the American university. Ann Arbor: University of Michigan Press.

Watterson, J.S. (2000). College football: History, spectacle, controversy. Baltimore: Johns Hopkins University Press.

What the Hell Has Happened to College Sports? And What Should We Do About It? (2011). Chronicle of Higher Education. Retrieved from http://chronicle.com/article/What-theHell-Has-Happened-to/130071/. 